\title{
Banned Bodies, Spurned Speech: Butler, Kristeva and the location of a 'maternal language'
}

\author{
Erin Wunker
}

\begin{abstract}
Cet article propose de revenir sur la critique que fait Butler de Kristeva, notamment sur la théorie du langage poétique. Butler mésinterprète la théorie de Kristeva et, ce faisant, mine son propre argument selon lequel le genre est performatif. En (re)venant à Butler et en me penchant sur Kristeva, j'aborde ensuite le discours féministe qui se demande comment traduire la théorie en pratique: comment le langage poétique de Kristeva peut-il fonctionner dans le sens d'un féminisme d'avenir? Relue du point de vue de Kristeva, la théorie de la performativité du genre de Butler peut-elle être réhabilitée? Comment un lien entre le langage poétique de Kristeva et la performance de Butler peut-il décentrer de façon productive la structure du pouvoir partriarcal hétérosexualisé?
\end{abstract}

Judith Butler has suggested that gender is a "cultural configuration" (Gender Trouble 190). She posits that gender categories are predicated on the grounds of exclusion, and what is at stake is the power of identity. I refer, here, to Butler's preceding remarks wherein she states that "the foundationalist reasoning of identity politics tends to assume that an identity must first be in place in order for political interests to be elaborated and, subsequently, political action to be taken" (181). She maintains, throughout her text, that in the present socio-cultural "configuration" a subject must be read as such-be culturally identifiable-in order to begin to enact political change. The thrust of Butler's argument is, in short, that gender is culturally prescribed to a subject (in order to render that subject identifiable), however, Butler takes great pains to demonstrate that gender is an arbitrary construction and that, as there are only two "culturally identifiable" genders, this process is inherently exclusionary. She maintains, moreover, that systematically categorizing gender works to undermine the subversive potential of individualistic identity. I will speak to this last point throughout the course of the paper. If power-moreover heterosexualized patriarchal power-is structured to exclude a majority of the population, then it follows that at the very least there should exist, within the excluded majority, a desire to subvert that power. It is curious, then, that Butler's critique of Julia Kristeva's "body politics" hinge on what Butler sees as an impossible and inadequate politics of subversion (102). Kristeva, in her work on subject-formation, relies on the multiple meanings available in language (what she calls poetic language) as a means by which to subvert the patriarchal law of power. Poetic language, for Kristeva, offers a way to reconnect with the 'maternal body'-a 'body' that psychoanalysis maintains every subject must turn from in order to enter into the socio-symbolic order. One could make the argument that 'figure' or 'specter' could work interchangeably 


\section{$148 \cdot$ Tessera}

with 'body,' however I choose to use 'body' deliberately as I read Kristeva as gesturing toward both the physical maternal body as well as the psychoanalytic concept of the Mother. Butler, herself, is engaged in an argument that positions the gendered body as performative. She claims that any categorization of gendered bodies is always a practice of exclusion (7). Yet, Butler resists Kristeva's subject-theories. She posits that Kristeva "offers us a strategy of subversion that can never become a sustained political practice" (103). This paper proposes to perform a return to Butler's critique of Kristeva, particularly her critique of Kristeva's theory of poetic language. I suggest that Butler fundamentally misinterprets Kristeva's subject-theory, and in doing so destabilizes her own pertinent argument that gender is performance. I will, in my (re)turn to Butler and my turn to Kristeva, enter into the feminist discourse that asks how theory can be translated into practice: I will ask how Kristeva's poetic language works toward a feminism of the future. Furthermore, when re-read through the same Kristeva she rejects, I will question whether Butler's performative theory of gender may be rehabilitated. The paper will close by attempting to postulate a link between Kristeva's poetic language and Butler's theory of performance that may locate a point at which to begin to practically de-center the heterosexualized patriarchal power structure.

Butler opens Gender Trouble with an ideological crux that has plagued the feminist movement since its inception. She underscores that the relationship between feminist discourse and political action is contentious: the task of feminist theory has been to formulate a language that "fully or adequately represents women" in order for women to become a visible group within politics (4). T h e problem, however, is at the very root of representation: for a language to adequately represent a group, that group must be visible (4). In short, the task of feminist theory is to create a language that would, paradoxically, operate under those same cultural codes it wishes to expose and to change.

The term "women" is necessary in so far as it indicates the group for whom it wishes to create political action, however, the very term glosses over the myriads of differences between women. Citing Michel Foucault, Butler further reveals the complexity of the feminist task. She notes, "Foucault points out that the juridical systems of power produce the subjects they subsequently come to represent" (4). Thus the "subject" of feminism, the one(s) on whose behalf feminism acts, is theoretically produced by the "very political system that is supposed to facilitate its emancipation" (4). Feminist theory must proceed critically, for power (juridical power in Butler's terms), has a dual function: it both produces subjects-before-the-law, and simultaneously conceals its production (5). The task for feminist theory, as Butler sees it, is not only to question how women may best be represented (made visible) in the political and linguistic realms, but also to come to an understanding of "how the category of 'woman,' the subject of feminism, is produced and restrained by the very structures of power through which emancipation is sought" (5). To be a subject-before-the-law is to stand before the Law and wait to be recognized, wait to be named. To be subject to and of the law is to be forced to wait in the periphery. Moreover, to wait to be made visible and 
wait to be named both disempowers the subject, and creates a false (as well as limiting) concept of a single identity. The power of the Law rests in the conception that to be recognized by the Law is to be recognized as $a$ subject.

As Butler notes, the language available for political and theoretical action is incredibly limiting: the "women" feminist theory works for are, by the single term "women," displaced from their own specificity (6). While women are certainly not all alike, feminist theory has taken up the linguistic tools available to make visible the people it works to help. Thus the disparity between Western women, Third World women, European women, Asian women, women of colour, poor women, wealthy women, middle class women, single mothers, women of various sexualities is bound up in a single word: 'women.' Butler's position is clear. She suggests that, "the presumed universality and unity of the subject of feminism is effectively undermined by the constraints of the representational discourse in which it functions" (7). She posits, moreover, that the insistence-and I would suggest the perceived necessity - of maintaining the universal subject of feminism has resulted in "multiple refusals to accept the category" (7).

A further complication for feminist theory arises when one begins to investigate the distinctions between sex and gender (9). While sex has been generally accepted as biologically (and therefore indisputably) determined, gender is the cultural (and therefore disputable) inscription that a sexed body is prescribed (10). Gender, unfixed and disputable, should assume the same task assigned to feminist theory: gender should work to reveal the politico-cultural discourse that produces it (11). Butler suggests that, "when the relevant 'culture' that 'constructs' gender is understood in terms of such a law or set of laws, then it seems that gender is determined and fixed as it was under the biology-is-destiny formulation. In such a case, not biology, but culture, becomes destiny" (12). In the same way that a group is made visible through its very designation as a group, bodies become culturally intelligible through being marked as one gender or another (13). The socio-politico-cultural realm makes meaning through language, thus, language becomes the prime 'maker' of sexed, gendered bodies. Thus, a simultaneous critical discourse must be taken up on the constitutive structure of language (13).

Feminist theory must determine what it means to be a subject in and of language. Within a discourse, which has figured women as either a lack, ${ }^{i}$ or an Other, Butler surmises that women also lack subjective agency. The constructed concept of "Being" ii is at the root of this complex discourse:

It was grammar (the structure of the subject and the predicate) that inspired Descartes' certainty that "I" is the subject of "think," whereas it is rather the thoughts that come to "me": at the bottom, faith in grammar simply conveys the will to be the "cause" of one's thoughts. The subject, the self, the individual, are just so many false concepts, since they transform into substances fictitious unities having at the start only a linguistic reality. (Haar 18) 
The subject of any discourse is so much fiction: language creates the misconception of a single, fixed identity and wholeness of being. Further, language, in the Saussurian model, is itself an arbitrary system. It is a fiction that has been wholeheartedly taken up, however. As Louis Althusser suggests, "there is no ideology except by the subject for subjects. Meaning, there is no ideology except for concrete subjects, and this destination for ideology is only made possible by the subject: meaning, by the category of the subject and its functioning" (130). Thus, to be a subject is to be subject to (and of) language. Butler's project, in the name of a politically effective feminist theory, is to crack open the linguistic fiction of sex and gender. In order to subvert the dominant, regulatory political discourse, sex, gender and the bodies they mark must be revealed as fictions. In so doing, feminist theory must interrogate not only the ways a subject is perceived to come into being, but also the ways in which a subject is interpolated into language. As I enter into a critique of Butler's (mis)reading of Kristeva's theory of poetic language I will momentarily outline the tenets of psychoanalytic discourse that form the foundations of Kristeva's writing. I will then turn to Butler's reading of Kristeva, and reread it alongside Kristeva's own words. Through this rereading, I hope to reveal that Kristeva's poetic language offers a means of discursive critique, as well as political efficacy, that Butler seeks.

The formation of a subject is, in the Freudian theory, an inherently violent process. The child undergoes a double-trauma; first, the child realizes his or her body is separate from the mother's, and second, the child realizes that different bodies are (culturally) invested with different degrees of power. That is to say, the child understands that to be marked female is a far different thing than to be marked male. iii For Freud, this realization is enacted through a psychical severing. He suggests that the child's primary investment is in his or her parents (1923, 369). The story is as follows: the child, in Freud's terminology a male child, first invests his love energy into the mother. This investment has to do primarily with the mother's breast-the child's source of nourishment. The trouble begins when the child's investment in his mother becomes sexualized, and he begins to feel a sense of competition with the father. A fear of castration arises out of the sense of competition: the child fears the father will eliminate his potential potency. The boy's fear of his father is detrimental to himself, for the boy identifies with the father. In other words, a fear of the father is, in some ways, a fear of the parts of himself that the boy recognizes in the father. Fear threatens the boy's psyche. Thus, the child pushes his desire for his mother, as well as his fear of his father, back into his unconscious. The entire oedipal process is a process of repression. The child must repress his primary investment and either strengthen his identification with the father, or simply identify with the mother. As the child represses his primary identification, he simultaneously represses an integral part of himself. Thus, the child's formation of an ego-ideal is built on a fissured foundation.

Girls undergo a similar process. In "Femininity" Freud addresses the subject-formation of girls. I draw this summary from Freud's 1933 essay "Femininity." In this version, the girl's object-cathexis, like the boy's, is first for her mother. The mother's position as object of love energy is, again, based 
primarily on her position as food source. Once more, the trouble begins at the point when the girl's love energy for her mother is no longer simply related to nourishment from her mother's breast. In order to progress "normally," the girl must transfer both her libidinal-cathexis and her object-cathexis from her mother to her father. She unconsciously justifies such an illogical and violent move by resenting her mother for her lack of penis. Moreover, her resentment for her mother, and her rejection of her own body in favour of the phallus causes, I would suggest, the girl's rejection of a primary self. Similar to her male counterpart, the female child represses a visceral and integral part of her earliest subjectivity. To be interpolated into society (where heterosexual desire is upheld as the norm) is to undergo a process of re-identification. A subject in society always operates with a fissured foundation. Freud suggests that a woman wishes to bear a child because she unconsciously believes that the child will fill her psychic lack: the child, a thing of worth, will, in turn fill her with worth and compensate for her lack of a phallus ("The Dissolution of the Oedipus Complex" 173). Already, in Freud, there is a gesture towards Kristeva's reworking of the Mother and poetics. Kristeva studied psychoanalysis with Jacques Lacan, and it is from Lacan's work that Kristeva most clearly draws.

Lacan takes up the Freudian fissured subject and reworks it into a linguistic theory of formation. ${ }^{\text {iv }}$ In Lacan's rendition of the search for selfhood, it is le nom du père, or Name-of-the-Father, that operates as the trump card in the desiring subject's quest for subjectivity. Le nom du père is what Lacan sees in language as the inherent gender inequity, which guarantees a certain (phallocentric) order $(1977,48)$. The Name-of-the-Father is, in short, a rereading of Freud's process of oedipalization. The Father lays down the laws of the family. ${ }^{\mathrm{v}}$ For Lacan, our most prevalent mode of communication is language, thus the law is a linguistic law, "this law, then, is revealed clearly enough as identical with an order of language" $(1977,66)$. Lacan posits that the child enters language - the Symbolic ${ }^{\mathrm{vi}}$ order-at an early age $(1977,1)$. Importantly, in the Lacanian reading, the child enters the Symbolic "held tightly as he is by some support" $(1977,1)$. The child manages a degree of mastery over his or her supporting structures and "jubilantly assumes his [sic] specular image" $(1977,2)$. In short, the child's entrance into the Symbolic comes through an opposition: the child forms an 'I' by pushing away the 'not I' (the supporting structures). Interestingly, Lacan figures the child's jubilant assumption as being predicated on a violent loss: "jouissance is suffering" (Lacan Seminar 7 184). In other words, the child's pleasure is founded on a repudiation of the "primary relationship with the maternal body" (Butler 101). Lacan maintains that the body of the child, the child's ability to conceive of him/herself as a separate entity, is only possible through a psychical repression and physical rejection of the Mother. What is necessary, in Butler's project, then, is a subversion of this linguistic hegemony that inscribes gender and regulates bodies. I would suggest, further, that an effective subversive critique must necessarily come from the margins of discourse. I do not mean to suggest that one must be utterly outside language and culture - such a suggestion would be impossible. 
Rather, I would suggest, as Kristeva does, that such a critique must be posited as a rupture (Reader 99).

Stemming from Husserlian phenomenology, Kristeva asserts that a critique of the law (doxa for Husserl, culture for Butler) must be strategically positioned as a rupture, or break, in the signifying process (Reader 98). Asserting itself from the periphery, this critical rupture may open a subversive space within the subject. Kristeva positions herself on the margins of discourse: she is both a stranger in the country in which she lives and works, and a stranger among her colleagues. ${ }^{\text {vii }} \mathrm{Her}$ task, as she saw it early in her career, was "to work on language, to labour in the materiality of that which society regards as a means of contact and understanding [is] to declare oneself a stranger/foreign [étranger] to language" (3). Kristeva's theory of a subject's formation uses Lacan's theory as a point of departure. She has, as Allison Weir notes, been criticized both for her adherence to the Lacanian notion of the Phallus, and for her virtual deification of motherhood (145). Nonetheless, I suggest that, through a reading of Kristeva's subject theory (itself a strategic re-formulation of Lacanian theory), we may uncover the tools for enacting the subversive critique that Butler seeks.

Kristeva's theory of subject formation, as I have suggested, draws heavily from the work of Lacan. However, as Weir points out, in Kristeva's work jouissance - pleasure - has infinite potential (150). Moreover, unlike Lacan and Freud, Kristeva figures the child's necessary repression, the repression of the Mother as primary love object, as a pleasurable process (Weir 151). Weir suggests, "the pleasure of differentiation, the pleasure of signification, the pleasure of identification with others, the pleasure of learning to participate in the social world, all are thematized by Kristeva as essential to the formation of self-identity" (151). At the root of this pleasure lies the subject's primary repression. This repression, unlike the repression of Freud, of Lacan, is a secreting-away of the primary self, what Weir translates as "an acceptance of otherness within the self," and what I would suggest is, in fact, the origin of the Freudian concept of the uncanny (152). In short, Kristeva believes that in order to accept the differences of others, we must accept the strangers within ourselves: we must accept that primary repression of our selves which remains in the unconscious. ${ }^{\text {viii }}$ To recognize strangeness within the self, and to find pleasure in the process of becoming a subject, is to reformulate the very concept of what a subject is. Weir notes that, with this concept of pleasure in mind, Kristeva's understanding of a subject in/of language is particularly unique:

[Kristeva] criticizes the structuralist understanding of language solely in terms of structure or system or code, and argues instead from a theory of language as a discursive practice of subjects. Thus, Kristeva's "poststructuralism" is unlike that of Derrida and Butler, who see the subject as nothing more than a reflection of function of the law of language, and who therefore want to move beyond the subject . . . Kristeva . . . argues for the reintroduction of the subject, the body and history into analyses of language - for, that is, an understanding of language in terms of human discourse. (153-4) 
Thus, Kristeva's theory of language, as well as her theory of the subject in/of language, points toward a radical alternative to both the Structuralists and many of the poststructuralists.

Revolution in Poetic Language is concerned with the "signifying process vis-à-vis general theories of meaning, theories of language and theories of the subject" $(1986,90)$. While refusing to utterly eschew the Freudian and Lacanian model of a fragmented subject, a subject comprised of "substance morcelée," Kristeva suggests that the subject in/of language is actually "in process/on trial" $(1986,91)$. While even this notion is imperfect, what Kristeva makes clear is the contentious "modalities that are inseparable within the signifying process that constitutes language . . . in other words, so-called 'natural' language allows for different modes of articulation of the semiotic and the symbolic" $(1986,93)$. Kristeva takes the term 'semiotic' from "its Greek sense: óçiåßï = distinctive mark, trace, index, precursory sign, proof, engraved or written sign, imprint, trace, figuration" $(1986,93)$. Put simply, the 'semiotic' is in the order of primary repression. The 'symbolic' may be understood in terms of the Lacanian model: language as uttered and understood through the Law. Unlike her predecessors, Kristeva suggests that there are both linguistic and non-linguistic systems that contribute to the subject's formation $(1986,93)$. Most importantly she posits, "because the subject is always both semiotic and symbolic, no signifying system he [sic] produces can be either 'exclusively' semiotic or 'exclusively' symbolic, and is instead necessarily marked by an indebtedness to both" $(1986,93)$. This is a substantially different reading than the one Butler presents in Gender Trouble. Butler reads Kristeva to say that:

The 'semiotic' is a dimension of language occasioned by that primary maternal body, which not only refutes Lacan's primary premise, but serves as a perpetual source of subversion within the Symbolic. For Kristeva, the semiotic expresses the original libidinal multiplicity within the very terms of culture, more precisely, within poetic language in which multiple meanings and semantic non-closure prevail. (102)

Butler goes on to suggest that "Kristeva's strategy of subversion proves doubtful," because it "appears to depend on the stability and production of precisely the paternal law she seeks to displace" (102). Butler appears to be reading into Kristeva a binary that is simply not there: while Butler reads the semiotic and the symbolic as divisible, Kristeva has clearly theorized that the two are siamesed concepts. As we have seen, Kristeva conceives of a subject that is neither wholly semiotic, nor utterly symbolic. Rather, the subject engages discursively with each. Moreover, Butler rejects the theory of poetic language as unequivocally related to a "prediscursive libidinal economy" that is meant both to subvert the regulatory terms of culture, and paradoxically cannot "be maintained within the 
terms of culture" (102). Yet, Kristeva tell us that poetic language is, "at least double. The word . . . thus turns out to occupy the status of mediator, linking structural models to cultural (historical) environment, as well as that of regulator, controlling mutations from diachrony to synchrony" $(1986,37)$. Instead of causing the psychic breakdown of a subject, poetic language both acknowledges the ruptures, and act as a means of 'articulating' what object-relations psychoanalyst Melanie Klein has called "the analytically unthinkable" $(1986,103)$. In short, Butler overlooks Kristeva's distinct use of psychoanalytic theory: poetic language functions as a means of articulating that which defies the structure of language. Rather than direct her interrogation to how poetic language may work for political practice after all, Butler embarks on a misreading of the psychoanalytic theory of drives (103).

Butler posits, in her critique of Kristeva, that, "the key to Kristeva's view of the psychotic nature of homosexuality is to be understood . . . in her acceptance of the structuralist assumption that heterosexuality is coextensive with the founding of the Symbolic" (107). This is a particularly poor translation of Kristeva's refiguration of the Freudian and Lacanian models of subject formation. One recalls that, for both Freud and Lacan, the child's subject formation is, indeed, a heterosexualizing process. One may also recall, though Butler clearly does not, that this process is enacted under the regulation of the (culturally constructed and maintained) Law of the Father. To be understood as a subject, the subject transfers his/her primary identification to the appropriate parent. The child is subject to the Law. However, Butler draws her critique on Kristeva from "Motherhood According to Giovanni Bellini." Butler says, "Kristeva suggests that, because the maternal body signifies the loss of coherent and discrete identity, poetic language verges on psychosis" (107). What Kristeva actually says is that, "the homosexualmaternal facet is a whirl of words, a complete absence of meaning and seeing; it is feeling, displacement, rhythm, sound, flashes, and fantasied clinging to the maternal body as a screen against the plunge" $(1980,240)$. The subject who is engaged in poetic language, importantly for Kristeva this is a female subject, is absolutely other to her self. She is strange to herself. The whirl of words that have no meaning are, I would suggest, indicators of the primary repressed self, the primordial self, the self of the child who did not need to read the marks of sex and gender. The subject who is strange to her self, who holds within herself absolute alterity, is, I would argue, more able to recognize and appreciate the alterity of others. ${ }^{\text {ix }}$ Furthermore, to suggest that Kristeva is making a Structuralist assumption is absurd. To be clear I will reference Deleuze and Guattari who posit, in Anti-Oedipus, that, "if desire is repressed, it is because every position of desire, no matter how small, is capable of calling into question the established order of a society" (116). Poetic language is the language of the desiring subject. It is the language of the primary repressed self. It is homosexual insofar as it has refused interpolation into the Law. Moreover, Kristeva's theory that "by giving birth, the woman enters into contact with her mother; she becomes, she is her own mother; they are the same continuity differentiating itself" is not the melancholic process Butler perceives it to be $(107,108)$. Rather, the metaphor ${ }^{\mathrm{x}}$ of birth, of motherhood is a potentially revolutionary act. 
Gayatri Spivak reads the metaphor of mothering to indicate a de-valuing of "normative essentialisms" (67). She goes on to say that it doesn't matter "if I have no children and therefore no experience of 'giving the mother to the other woman.' It is a general sense of mothering-its minimal definitive and presupposed cultural predication as selfless love . . . a relationship with the other woman-who is precisely not a child of my body" (68). Poetic language is not evidenced through the formulation of "lesbian sexuality as intrinsically unintelligible," nor is it a "tactical dismissal and reduction of the lesbian experience performed in the name of the law," as Butler suggests (111). Rather, poetic language is the language that defies that law, it "puts the subject in process/on trial through a network of marks and semiotic facilitations . . . the moment it stops being mere instinctual glossolalia and becomes part of the linguistic order, poetry meets up with denotation and enunciation-verisimilitude and the subject-and, through them, the social" $(1986,110)$. In short, what Butler overlooks is the performative potential of poetic language.

Butler brings her critique of Kristeva to a close with the suggestion that, "if subversion [of the Law] is possible, it will be a subversion from within the terms of the law, through the possibilities that emerge when the law turns against itself and spawns unexpected permutations of itself" (119). In other words, a politically effective subversion of the law that regulates and marks bodies would have to occur within the very structures of that law. The subversive action would have to be read and understood as performative. As set out in speech-act theory, performative language is language that "does not simply make a statement, but also performs an action" (Austin 5-6). Butler suggests that the gendered body is performative, insofar as the "essence or identity that [it] otherwise purport[s] to express are fabrications manufactured and sustained through corporeal signs and other discursive means" (173). If we begin to understand the bodies we inhabit in terms of their gendered performativity, then "the political regulations and disciplinary practices" that produce these gendered bodies may be made visible, and critiqued (Butler 174). The question then becomes what language to use to critique these bodies, and whether the subject may ever be engaged in subverting the law while remaining intelligible by that same law. I would suggest that Kristeva's subject in process/on trial does just that. The subject in process/on trial can be read as "the mobile, unfixed, subversive writing subject" (Moi in Kristeva 1986, 89). Further, the subject in process/on trial is a subject engaged with poetic language. As Butler suggests, at the beginning of Gender Trouble, to be subject to/of the law is a paradoxical concept. Feminist theory has struggled with the problem of representation because of this paradox. I would suggest that what Butler misses in Kristeva's theory of poetic language is the inherent concept of movement: poetic language moves faster than the structures that wish to fix it in place. For feminist theory to harness the power of poetic language would be to harness the Kristevan jouissance of the primal, unmarked body. I suggest that this is possible through a strategic feminist model of performative writing.

Peggy Phelan posits that, "performative writing enacts the death of the 'we' that we think we are before we begin to write. A statement of allegiance to 
the radicality of unknowing who we are becoming, this writing pushes against the normative ideology that insists that we die once in an expository, teleologically driven future" (17). Moreover, Phelan suggests, "performative writing is an attempt to find a form for "what philosophy wishes all the same to say" (11). Performative writing operates from the margins of discourse, toward the center: its form resists structure, while its content engages in discourse. Feminist theory must conceive of a manner of writing the political performatively, from the margins, toward the center. A performative critique of the Law would be a critique that not only speaks, but also acts. ${ }^{\mathrm{x}}$

\section{Notes}

i Butler is, of course, drawing this from Luce Irigaray, who suggests that "woman" is multiple, rather than singular and fixed (15). Irigaray posits, moreover, that "woman" cannot be adequately represented through language, "woman" is inarticulable. For a more comprehensive discussion of woman-as-lack see Irigaray's Ce Sexe qui n'en est pas un, as well as Speculum of the Other Woman.

ii Clearly, as Butler cites Haar who, in turn, references Descartes, the notions of "Being" taken up here are in the tradition of Enlightenment thinking. Though it is beyond the scope of this paper, it is pertinent to note that, in Strangers to Ourselves, Kristeva posits an earlier, different notion of the subject as put forth by Montesquieu.

iii Critics of Freud often overlook two points: first, Freud began his practice in a socio-historical moment as well as a geographic location (Vienna) that had incredibly structured gender divisions. Men were certainly granted far more social and economic power than women. Secondly, Freud's patients were mainly upper and upper middle class women who were extremely restricted in both their social and physical movement. For a more complex discussion of this see Freud's and Breuer's case studies of hysterics. The case history of Anna O. is particularly compelling as an early example.

iv Lacan draws from Saussure, but it is the work of structural anthropologist Claude Lévi-Strauss that initiates Lacan's decisive "linguistic turn" (Evans 102). It is Lacan's theory of the unconscious - that it is structured like language - that most clearly places him within the Structuralist discourse. As I shall go on to suggest, it is Kristeva's reluctance to absolutely claim Structuralism as her own that puts her theory of poetic language in a position to elucidate Butler's work.

$v$ Though it is beyond the scope of this paper, it is important to note that the law of the family is based on a prohibition of incest. See Freud's Totem and Taboo, and well as Lacan's "The function of the letter in the unconscious or reason since Freud". vi This is a great simplification of the Lacanian Symbolic order. The Symbolic, for Lacan, is drawn from the anthropological work of Lévi-Strauss who posits that society (culture) is structured by "certain kinship relations and gift-economies" (Evans 201). Thus, for Lacan, the Symbolic takes up notions of gift-giving and 
circuits of exchange. Moreover, the Symbolic is not simply the order of language, though, as Evans points out, the dual concepts of Law and Structure cannot exist without Language (201). Thus "the symbolic realm of language is the signifier; a dimension in which elements have no positive existence but which are constituted purely by virtue of their mutual differences. . . . The Symbolic is also the realm of radical alterity" (Evans 202).

vii In her introduction to The Kristeva Reader Toril Moi notes that Kristeva was one of very few women who worked within the intellectual climate of the TelQuel group. Kristeva herself suggests that her position as a gendered minority had a direct effect on her work: "It was perhaps necessary to be a woman to attempt to take up that exorbitant wager of carrying the rational project to the outer borders of the signifying venture of men" (qtd. by Moi in Reader 3 ).

viii Kristeva discusses this concept of strangeness at length in her text Strangers to Ourselves. My suggestion that the concept of the Uncanny may, in fact come from a periodic recognition of the primary repressed self (hence the strange familiarity) draws on the final chapter of this text.

ix My suggestion comes from a reading of Kristeva's Strangers to Ourselves wherein she posits that a recognition of our own strangeness could lead to a politics of cosmopolitanism that avoids the erasure of difference, instead figuring difference as an inevitable and important facet of every day life in the globalized world.

x Butler's reading of motherhood and birthing is presented as a particularly literal reading that overlooks Kristeva's use of metaphor. According to Paul Ricouer, the metaphor points to "that sort of discourse that has no denotation but only connotations" (122). In other words, metaphors gesture towards that which cannot be said directly.

${ }^{x i}$ (What is the impact of the belief-psychoanalytic and philosophical-that the female body is situated around a 'lack'? Moreover, what is the impact of being told I do not exist? If, as Freud suggests, I form my self through a process of violent wounding and repression, then how am I to stage a return to my self? It is as though I exist only on the periphery, in parenthesis. Am 'I' to exist always in the margins . . . on the periphery . . . buried in a footnote? No. What are the powers of performance but an embodiment of subversive acts? 'I' will process, perform from the margins and toward the center in order to destabilize matrix of power, for, things fall apart, and the structure cannot hold . . .) 


\section{Works Cited}

Althusser, Louis. "Ideology and Ideological State Apparatuses." Lenin and Philosophy and Other Essays. London: Routledge, 1971.

Adorno, Theodor W. and Horkheimer, Max. Dialectic of Enlightenment. Trans. John Cumming. New York: Continuum, 1972.

Austin, John L. How to Do Things With Words. Cambridge, Mass.: Harvard UP, 1975. Butler, Judith. Gender Trouble: Feminism and the Subversion of Identity. New York and London: Routledge, 1990.

Deleuze, Gilles, and Guattari, Felix. Anti-Oedipus: Capitalism and Schizophrenia. Trans. Robert Hurley, Mark Seem and Helen R. Lane. Minneapolis: U of Minnesota P, 1983.

Derrida, Jacques. The Ear of the Other. Ed. Christie MacDonald. New York: Shocken Books, Inc., 1985.

Evans, Dylan. An Introductory Dictionary of Lacanian Psychoanalysis. Hove and New York: Brunner-Routledge, 1996.

Foucault, Michel. The History of Sexuality, Volume 1, An Introduction. Trans. Robert Hurley. New York: Vintage, 1980.

Freud, Sigmund. "The Dissolution of the Oedipus Complex." Standard Edition of the Complete Psychological Works of Sigmund Freud XIX. Ed. and Trans. James Strachey. London: Hogarth Press and the Institute of Psychoanalysis, 1989. — "The Ego and the Id." 1923. On Metapsychology. Ed. Albert Dickson. Trans. James Strachey. New York: Penguin Books Ltd., 1991.

— "Femininity" 1933. Women and Analysis: Dialogues on Psychoanalytic Views of Femininity. Boston: G.K. Hall, 1985. 17-26.

- On Metapsychology. 1915. Ed. Albert Dickson. Trans. James Strachey. New York: Penguin Books Ltd., 1991.

— "On Narcissism." 1914. New Introductory Lectures on Psychoanalysis. Ed. Angela Richards. Trans. James Strachey. New York: Penguin Books Ltd., 1973. Haar, Michel. "Nietzsche and Metaphysical Language." The New Nietzsche: Contemporary Styles of Interpretation. Ed. David Allison. New York: Delta, 1977. Irigaray, Luce. Speculum of the Other Woman. Trans. Gillian C. Gill. Ithaca: Cornell UP, 1985.

- Ce Sexe qui n'en est pas un. Paris: Éditions de Minuit, 1977.

Lacan, Jacques. Écrits: A Selection. Trans. Alan Sheridan. New York: W.W. Norton, 1977.

— "The Mirror Stage as Formative of the Function of the I." Ecrits: A Selection. Trans. Alan Sheridan. New York: W.W. Norton, 1977. 1-7.

- Four Fundamental Concepts of Psychoanalysis. Trans. Alan Sheridan. London: Hogarth Press and the Institute of Psychoanalysis, 1977.

- Seminar VII: The Ethics of Psychoanalysis. Trans. Dennis Porter. London: Routledge, 1992.

Kristeva, Julia. Desire in Language: A Semiotic Approach to Literature and Art. Trans. Leon S. Roudiez. New York: Columbia UP, 1980. 
- "Motherhood According to Giovanni Bellini." Desire in Language: A Semiotic Approach to Literature and Art. Trans. Leon S. Roudiez. New York: Columbia UP, 1980. 237-270.

- Powers of Horror: An Essay on Abjection. Trans. Leon S. Roudiez. New York: Columbia UP, 1982.

- Revolution In Poetic Language. Trans. Margaret Waller. New York: Columbia UP, 1984.

- Strangers to Ourselves. Trans. Leon S. Roudiez. New York: Columbia UP, 1991. - The Kristeva Reader. Ed. Toril Moi. New York: Columbia UP, 1986. Phelan, Peggy. Mourning Sex: Performing Public Memories. New York and London: Routledge, 1997.

Ricoeur, Paul. The Rule of Metaphor: Multi-Disciplinary Studies of the Creation of Meaning in Language. London: Routledge, 1978.

Spivak, Gayatri Chakravorty. "French Feminisim Revisited: Ethics and Politics." Feminists Theorize the Political. Ed. Judith Butler, Joan W. Scott. New York and London: Routledge, 1992. 54-85.

Weir, Allison. Sacrificial Logics: Feminist Theory and the Critique of Identity. New York: Routledge, 1996. 